\title{
Postępy w leczeniu wspomagającym u chorych na nowotwory układów chłonnego i krwiotwórczego
}

\author{
Advances in the supportive treatment of patients \\ with lymphoid and myeloid malignancies
}

\author{
Anna Czyż \\ Katedra i Klinika Hematologii i Transplantacji Szpiku, Uniwersytet Nauk Medycznych im. Karola Marcinkowskiego, Poznań
}

\begin{abstract}
Streszczenie
Poprawa skuteczności leczenia wspomagajacego u chorych na nowotwory hematologiczne może w istotny sposób wplywać na wyniki prowadzonej chemioterapii, a także na jakość życia osób, u których nowotwór zostanie wyleczony. W pracy omówiono postępy, jakie się dokonaty w tej dziedzinie $w$ ostatnich latach. Przedstawiono nowe dane dotyczqce skuteczności czynników stymulujacych kolonie granulocytów w profilaktyce gorqczki neutropenicznej indukowanej chemioterapiq u chorych na chtoniaki nie-Hodgkina i ostre biataczki limfoblastyczne. Omówiono aktualne poglady na temat roli pierwotnej i wtórnej kardioprotekcji u chorych leczonych antracyklinami. Skomentowano również wyniki badań, których celem byta ocena skuteczności analogów gonadoliberyny w ochronie czynności jajników u kobiet poddawanych chemioterapii z powodu chtoniaka Hodgkina. Poruszono takie zagadnienia zwiazane $z$ odmiennymi sposobami prowadzenia leczenia wspomagajacego $u$ chorych $w$ starszym wieku.
\end{abstract}

Słowa kluczowe: krwiotwórcze czynniki wzrostu, gorączka neutropeniczna, chemioterapia, działania niepożądane, osoby w podeszłym wieku

Hematologia 2015; 6, 1: 77-84

\begin{abstract}
Treatment outcomes may be improved by advances achieved in supportive care for patients with hematological malignancies, thereby favourably impacting the quality of life for those surviving. This review focuses on recent progress in such care for patients undergoing chemotherapy. Latest study results are presented on the role of granulocyte-colony stimulating factor in prophylaxis of febrile neutropenia in patients with lymphoid malignancies. Also discussed, are the function of primary and secondary cardio-protection in patients treated with anthracyclines, as well as the protective effect of gonadotropin-releasing analogues on fertility and gonadal function in female survivors after treatment of Hodgkin lymphoma. In addition, the specific palliative care targeted at the elderly are presented.
\end{abstract}

Key words: hematopoietic growth factors, febrile neutropenia, chemotherapy, adverse events, elderly

Hematologia 2015; 6, 1: 77-84

Adres do korespondencji: Anna Czyż, Katedra i Klinika Hematologii i Transplantacji Szpiku, Uniwersytet Medyczny im. Karola Marcinkowskiego, ul. Szamarzewskiego 84,60-569 Pozná, e-mail: aczyz@onet.eu 


\section{Wprowadzenie}

Leczenie wspomagające $\mathrm{u}$ chorych na nowotwory układów chłonnego i krwiotwórczego $\mathrm{w}$ istotny sposób wpływa na skuteczność terapii przeciwnowotworowej. Przestrzeganie zasad leczenia wspomagającego umożliwia utrzymanie gęstości i intensywności dawki chemioterapii, a tym samym bezpośrednio rzutuje na jej skuteczność. Właściwe oszacowanie ryzyka powikłań hematologicznych i pozahematologicznych, jak również skuteczne zapobieganie ich wystąpieniu pozwala na względnie bezpieczne przeprowadzenie intensywnych programów chemioterapii nawet $\mathrm{u}$ chorych $\mathrm{w}$ starszym wieku. Jednym $\mathrm{z}$ celów leczenia wspomagającego jest także obniżenie ryzyka wystąpienia odległych powikłań chemioterapii, które istotnie wpływają na jakość lub czas życia osób, u których uzyskano trwałe wyleczenie $z$ pierwotnej choroby nowotworowej.

\section{Profilaktyka gorączki neutropenicznej indukowanej chemioterapią}

Jednym $z$ kluczowych celów leczenia wspomagającego $\mathrm{u}$ chorych na nowotwory jest zapobieganie powikłaniom infekcyjnym $\mathrm{w}$ przebiegu neutropenii indukowanej chemiotetarapią. Wyniki prac publikowanych w ostatnich latach potwierdzają korzystny wpływ stosowania czynników stymulujących kolonie granulocytów (G-CSF, granulocyte-colony stimulating factor) na częstość występowania gorączki neutropenicznej (FN, febrile neutropenia) indukowanej chemioterapią u chorych na nowotwory układów chłonnego. Zgodnie $z$ powszechnie przyjętymi wytycznymi europejskich i amerykańskich ekspertów zastosowanie G-CSF jest rekomendowane w pierwotnej profilaktyce FN u chorych na nowotwory układu chłonnego i guzy lite, u których ryzyko wystąpienia FN związane ze stosowanym protokołem chemioterapii wynosi co najmniej $20 \%$ [1, 2]. W przypadku realizowania schematów chemioterapii obarczonych pośrednim, tj. 10-20-procentowym ryzykiem wystąpienia FN, podejmując decyzję o zastosowaniu G-CSF, należy wziąć pod uwagę obecność dodatkowych czynników związanych $z$ chorym (wiek, zaawansowanie choroby nowotworowej, płeć, stan sprawności i odżywienia, niedokrwistość, poważne przewlekłe choroby współistniejące), które to ryzyko modyfikują. W pracy Chao i wsp. [3] potwierdzono istotny wpływ chorób wspólistniejących na ryzyko wystąpienia $\mathrm{FN} \mathrm{u}$ chorych na chłoniaki nie-Hodgkina (NHL, non-Hodgkin lymphoma).
Badacze przeprowadzili retrospektywną analizę danych 2480 chorych leczonych $z$ powodu NHL w latach 2000-2009 w ośrodku Kaiser Permanente Southern Kalifornia, u których nie stosowano G-CSF w pierwotnej profilaktyce FN. Z badania wykluczono chorych, którzy byli leczeni według schematów chemoterapii o dużej gęstości dawki oraz chorych poddanych przeszczepieniu krwiotwórczych komórek macierzystych. Wystąpienie FN oceniano po pierwszym cyklu chemioterapii. U 60\% chorych stosowano chemioterapię według schematu R-CHOP (rytuksymab, cyklofosfamid, doksorubicyna, winkrystyna, prednizon). Pierwszy cykl leczenia był powikłany FN u 238 (9,5\%) chorych. Istotnie wyższe ryzyko wystąpienia $\mathrm{FN}$ wiązało się ze współwystępowaniem niedokrwistości, infekcji ludzkim wirusem niedoboru odporności (HIV, human immunodefiency virus) i chorób reumatologicznych. Dodatkowo u pacjentów z chorobami nerek oraz chorobą wrzodową dwunastnicy stwierdzono statystycznie granicznie zwiększone ryzyko FN. Uzyskane wyniki potwierdzily wplyw przewlekłych chorób wspólistniejące na ryzyko wystąpienia FN u chorych leczonych $z$ powodu NHL. Choroby te stanowią zatem uzasadnienie dla profilaktycznego stosowania G-CSF w przypadku leczenia według protokołów chemioterapii, które wiążą się $z$ pośred$\operatorname{nim}(10-20 \%)$ ryzykiem wystapienia FN.

W ostatnich latach opublikowano równie $\dot{z}$ badania, które dostarczają kolejnych dowodów na skuteczność G-CSF w zapobieganiu FN u chorych na nowotwory układu chłonnego. Wang Li i wsp. [4] przeprowadzili metaanalizę wyników 30 randomizowanych badań klinicznych, których celem była ocena skuteczności stosowania G-CSF w pierwotnej profilaktyce FN u chorych na NHL lub guzy lite. W pracy tej wykazano, że ryzyko wystąpienia FN we wszystkich cyklach chemioterapii ulega znamiennemu obniżeniu dzięki zastosowaniu pegfilgrastymu (iloraz szans [OR, odds ratio] 0,25 ), filgrastymu (OR 0,42), lenograstymu (OR 0,34$)$ lub lipegfilgrastymu $(\mathrm{OR} 0,35) \mathrm{w}$ porównaniu $\mathrm{z}$ placebo lub brakiem pierwotnej profilaktyki. Ponadto stwierdzono również, że pegfilgrastym jest skuteczniejszy w redukcji ryzyka $\mathrm{FN}$ niż filgrastym (OR 0,61). Do podobnych wniosków prowadziła wcześniej opublikowana metaanaliza Coopera i wsp. [5], która obejmowała wyniki 30 randomizowanych badań dotyczących stosowania różnych postaci G-CSF w pierwotnej profilaktyce FN u ponad 5000 chorych na NHL i guzy lite. Podobnie jak w badaniu Wang Li i wsp. stosowanie pegfilgrasty$\mathrm{mu}$, filgrastymu, lenograstymu lub lipegfilgrastymu znamiennie obniżała ryzyko $\mathrm{FN}$ w porównaniu 
z placebo (OR 0,51; p < 0,0001), a pegfilgrastym okazał się skuteczniejszy od filgrastymu (OR 0,66 ; $\mathrm{p}=0,04)$.

Czynniki stymulujące kolonie granulocytów znalazły również zastosowanie w leczeniu wspomagającym u chorych na ostre białaczki limfoblastyczne (ALL, acute lymphoblastic leukemia). Postęp w leczeniu ALL u dorosłych, który nastąpił $\mathrm{w}$ ostatniej dekadzie, wynika między innymi $z$ intensyfikacji chemioterapii, której bezpieczne przeprowadzenie jest możliwe dzięki profilaktycznemu podawaniu G-CSF. Zastosowanie tych czynników skróciło czas trwania ciężkiej neutropenii, zmniejszyło częstość występowania infekcji i poprawiło zgodność prowadzonego leczenia $z$ zaplanowanymi protokołami terapeutycznymi, co wykazano w kilku prospektywnych, randomizowanych badaniach klinicznych. Giebel i wsp. [6] przeprowadzili po raz pierwszy analizę, której celem była ocena wpływu stosowania G-CSF na odległe wyniki leczenia ALL. Analizie poddano dane pochodzące $z$ pięciu prospektywnych randomizowanych badań przeprowadzonych we Francji, Polsce, Szwecji, Austrii i Australii, w których G-CSF stosowano w czasie pierwszego cyklu indukującego remisję. Wyniki leczenia 185 chorych na ALL, którzy otrzymywali profilaktycznie G-CSF, porównano $\mathrm{z}$ wynikami uzyskanymi u 162 chorych $z$ grup kontrolnych, w których takiej profilaktyki nie stosowano. Stwierdzono istotnie dłuższy czas trwania remisji u chorych, którym podawano G-CSF (33 miesiące $v$. 17 miesięcy; $\mathrm{p}=0,007$ ), a także większe prawdopodobieństwo 5-letniego przeżycia wolnego od białaczki ( $38 \%$ v. $24 \% ; \mathrm{p}=0,01)$ i przeżycia całkowitego (OS, overall survival) (32\% v. 23\%; $\mathrm{p}=0,07)$. Różnice w odległych wynikach leczenia były szczególnie wyraźne w grupie chorych na T-komórkowe ALL. Autorzy wysunęli przypuszczenie, $\dot{z}$ e poprawa wyników może się wiązać $z$ rzadszymi odstępstwami od protokołów leczniczych dzięki zastosowaniu G-CSF. Było to pierwsze badanie oparte na wynikach prospektywnych badań, w którym bezpośrednio udokumentowano wpływ stosowania G-CSF $\mathrm{w}$ pierwotnej profilaktyce na przeżycie wolne od choroby pacjentów z nowotworami.

\section{Powikłania sercowo-naczyniowe}

Do pozahamotologicznych powikłań, które bezpośrednio wpływają na czas życia chorych leczonych wcześniej z powodu nowotworu układów chłonnego lub krwiotwórczego, należą powikłania sercowo-naczyniowe. Powikłania te, indukowane przede wszystkim leczeniem antracyklinami, sta- nowią drugą po wznowie nowotworu przyczynę późnych zgonów u chorych poddawanych chemioterapii. Dysfunkcję lewej komory serca stwierdza się u ponad $25 \%$ chorych, którzy w trakcie leczenia otrzymali kumulacyjną dawkę doksorubicyny przekraczającą 400-550 mg/m² [11]. Ryzyko wzrasta, jeżeli antracykliny stosuje się w skojarzeniu $z$ innymi kardiotoksycznymi cytostatykami, takimi jak cyklofosfamid, ifosfamid, cisplatyna lub alkaloidy Vinca, a także w przypadku stosowania radioterapii. W 2012 roku opublikowano wytyczne ESMO (European Society for Medical Oncology) dotyczące postępowania u chorych leczonych antracyklinami [12]. Zgodnie $z$ zaproponowanym algorytmem postępowania u każdego chorego przed podaniem antracyklin powinno się wykonać badanie echokardiograficzne w celu wyjściowej oceny frakcji wyrzutowej lewej komory (LVEF, left ventricular ejection fraction). Do oceny czynności mięśnia sercowego można również wykorzystać inne nowoczesne metody obrazowania serca, takie jak rezonans magnetyczny lub wielobramkowa angiografia radioizotopowa (MUGA, multigated radionuclide angiography). Badanie powinno być powtarzane po 3, 6 , 9, 12 i 18 miesiącach od rozpoczęcia leczenia (stopień rekomendacji IA). U chorego, który otrzymał kumulacyjną dawkę doksorubicyny $240 \mathrm{mg} / \mathrm{m}^{2} \mathrm{lub}$ większą (albo epirubicyny $360 \mathrm{mg} / \mathrm{m}^{2}$ ) badanie należy powtórzyć po 4 i 10 latach. Jeżeli w badaniu obrazowym zostanie wykazana dysfunkcja lewej komory serca, to należy rozpocząć leczenie niewydolności lewej komory serca inhibitorem konwertazy angiotensyny (ACE, angiotensin-converting enzyme) i beta-adrenolitykiem zgodnie z ogólnymi wytycznymi dotyczącymi leczenia niewydolności serca. Prawdopodobieństwo powrotu prawidłowej czynności lewej komory jest większe, jeżeli leczenie kardiologiczne zostanie rozpoczęte w ciagu 2 miesięcy od zakończenia chemioterapii. $Z$ tej przesłanki wynika alternatywny sposób monitorowania czynności lewej komory zaproponowany przez ekspertów ESMO, w którym zakłada się oznaczenia stężenia troponiny I przed każdym cyklem leczenia obejmującym podanie antracykliny (stopień rekomendacji IIIB). U chorego, u którego stwierdza się podwyższone stężenie troponiny I, proponuje się rozpoczęcie leczenia enalaprilem, nawet jeżeli w badaniu echokardiograficznym nie stwierdzono zaburzeń czynności lewej komory. Badanie echokardiograficzne u chorego, u którego stwierdzono podwyższone stężenie troponiny I w trakcie leczenia antracyklinami, powinno być powtarzane co pół roku przez 5 lat po zakończeniu chemioterapii. 
Kalam i wsp. [13] przeprowadzili metaanalizę, której wyniki stanowią uzasadnienie dla stosowania pierwotnej lub wczesnej wtórnej kardioprotekcji farmakologicznej u chorych leczonych antracyklinami. Metaanalizą objęto 12 prospektywnych randomizowanych badań i 2 badania obserwacyjne, których celem była ocena pierwotnej kardioprotekcji farmakologicznej u chorych leczonych antracyklinami $z$ powodu guzów litych, nowotworów układu chłonnego lub ostrych białaczek. U ponad 2000 chorych oceniano wpływ pierwotnej kardioprotekcji beta-adrenolitykami (3 badania), statynami ( 2 badania), inhibitorem ACE (2 badania), inhibitorem ACE i beta-adrenolitykiem (1 badanie) lub deksrazoksanem (7 badań) na wystąpienie punktów końcowych, jakimi były spadek LVEF i/lub objawy niewydolności serca. Ryzyko wystąpienia dysfunkcji lewej komory w grupie, w której stosowano pierwotną kardioprotekcję, było znamiennie niższe niż w grupie bez kardioprotekcji (wspó1czynnik ryzyka $[\mathrm{RR}$, risk ratio] 0,33; $\mathrm{p}<0,0001$ ). Redukcja ryzyka wyrażona przez statystyczny RR dzięki zastosowanie inhibitorów ACE, beta-adrenolityków, statyn lub deksrazoksanu wyniosła odpowiednio $0,11(\mathrm{p}<0,0001), 0,31(\mathrm{p}=0,001)$, $0,31(\mathrm{p}=0,01)$ i $0,35(\mathrm{p}<0,0001)$. Należy się spodziewać, że prospektywne badania pozwolą w najbliższej przyszłości ocenić skuteczność wczesnej wtórnej kardioprotekcji stosowanej na podstawie pomiarów stężenia troponiny I lub innych biomarkerów uszkodzenia mięśnia sercowego w zapobieganiu wystąpieniu klinicznie jawnych zaburzeń czynności lewej komory serca.

\section{Zaburzenia czynności gonad}

Późnym niehematologicznym powikłaniem, które w istotny sposób rzutuje na jakość życia młodych chorych leczonych chemioterapią, jest trwała utrata czynności gonad i płodności. Problem ten wiąże się ściśle ze zwiększeniem intensywności stosowanych współcześnie protokołów polichemioterapii. Jednym ze sposobów ochrony gonad przed toksycznym działaniem cytostatyków jest profilaktyczne stosowanie analogów gonadoliberyny (GnRH, gonadotropin-releasing hormone) u kobiet poddawanych leczeniu przeciwnowotworowemu. Skuteczność takiego postępowania badano w kilku prospektywnych randomizowanych badaniach, których wyniki prowadziły jednak do sprzecznych wniosków. Ocena czynności gonad i płodności oraz skuteczności analogów GnRH w zapobieganiu uszkodzeniu jajników u chorych na chłoniaka Hodgkina (HL, Hodgkin lymphoma) leczonych chemioterapią według eskalowanego protokołu BEACOPP (bleomycyna, etopozyd, doksorubicyna, cyklofosfamid, winkrystyna, prokarbazyna, prednizon) była przedmiotem badania przeprowadzonego przez niemiecką grupę GHSG (German Hodgkin Study Group) [14]. Badaniem objęto 263 kobiety w wieku 18-45 lat w remisji całkowitej choroby utrzymującej się przez rok lub dłużej, które wcześniej były leczone 4 cyklami ABVD (adriblastyna, bleomycyna, winblastyna, deksametazon) (grupa A) lub 2 cyklami BEACOPP w dawkach eskalowanych (BEACOPPesk) i 2 cyklami ABVD (grupa B ,2+2”) $z$ powodu wczesnego stadium HL i obecności niekorzystnych czynników rokowniczych w ramach prospektywnego badania GHSG HD14. Charakterystyka chorych była podobna w obu badanych grupach, poza wyższym odsetkiem chorych przyjmujących agonistę GnRH w grupie B ,2+2” (29\%) w porównaniu $z$ grupą A , $4 \times \mathrm{ABVD} "(19 \%)$. Odsetek prawidłowych krwawień miesięcznych u kobiet $\mathrm{z}$ grup A i B był podobny (odpowiednio $84 \%$ i $74 \%$ u chorych w wieku $>30$ lat oraz $>90 \%$ $\mathrm{u}$ chorych młodszych), natomiast parametry hormonalne - hormon folikulotropowy (FSH, follicle-stimulating hormone) i hormon anty-Müllerowski (AMH, anti-Müllerian hormone) - wykazywały lepiej zachowaną funkcję jajników w grupie A, tj. leczonej wyłącznie ABVD. Odsetek ciąż był jednak większy w grupie B, leczonej „2+2”, niz w grupie $\mathrm{A}(26 \% v .15 \% ; \mathrm{p}=0,043)$, nie odbiegając od odsetka charakterystycznego dla niemieckiej populacji ogólnej. W analizie wielowariantowej wykazano, że stosowanie analogów GnRH było niezależnym, silnym czynnikiem prognostycznym dla zachowania płodności u kobiet poddanych chemioterapii $4 \mathrm{cy}$ klami ABVD lub 2 cyklami BEACOPPesk i 2 cyklami ABVD (OR 12,9; $\mathrm{p}=0$ 0,001). Jest to ważne spostrzeżenie o istotnym znaczeniu praktycznym. Niestety, wyniki opublikowanego w 2013 roku kolejnego badania GHSG, które dotyczyło oceny czynności jajników u kobiet leczonych 6 -8 cyklami BEACOPPesk $z$ powodu zaawansowanego stadium HL, nie potwierdziły ochronnego działania agonistów GnRH w przypadku stosowania chemioterapii o wysokiej intensywności [15]. Tylko u 45\% chorych w wieku powyżej 30 lat doszło do powrotu prawidłowych krwawień miesięcznych, a odsetek kobiet, które zaszły w ciążę po leczeniu 6-8 cyklami BEACOPPesk, wyniósł zaledwie $15 \%$, mimo że ponad połowa chorych deklarowała starania o koncepcję. Stosowanie agonistów GnRH w tej grupie intensywnie leczonych chorych nie wpływało na zachowanie płodności. Autorzy omawianych prac podkreślają, że jedynie prospektywne, randomizo- 
wane badanie mogłoby prowadzić do ostatecznego wyjaśnienia wpływu stosowania analogów $\mathrm{GnRH}$ na zachowanie czynności gonad $\mathrm{u}$ chorych leczonych $z$ powodu HL według protokołów chemioterapii o pośrednim stopniu intensywności.

\section{Leczenie wspomagające u chorych w starszym wieku}

Szczególne wyzwania związane z leczeniem wspomagającym niesie za sobą terapia nowotworów hematologicznych u osób w starszym wieku. W tej grupie chorych szczególnie istotne jest właściwe oszacowanie ryzyka wystąpienia poważnych powikłań indukowanych chemioterapią. Do coraz powszechniej uznanych metod oceny indywidualnego ryzyka leczenia onkologicznego zalicza się całościową ocenę geriatryczną (CGA, Comprehensive Geriatric Assessment), z wykorzystaniem między innymi skali oceny podstawowych czynności dnia codziennego (ADL, Activities of Daily Living) (tab. 1) lub złożonych (iADL, instrumental $A D L$ ) (tab. 2) oraz skal służących do oceny wpływu chorób współistniejących (CCI, Charlson Comorbidity Index - tab. 3; CIRS-G, Cumulative Illness Rating Scale for Geriatrics — tab. 4 [16]) na przewidywane przeżycie chorego [7, 8]. Narzędzia te powinny być coraz szerzej wykorzystywane w codziennej praktyce. $Z$ wymienionymi skalami oraz ich praktycznym zastosowaniem polskiego czytelnika zapoznali Warzocha i wsp. w pracy dotyczącej leczenia przewlekłej białaczki limfocytowej u osób w podeszłym wieku opublikowanej w czasopiśmie „Hematologia” 2014; 5 (4): 285-295.

Ponadto w ostatnich latach zidentyfikowano również zaburzenia metaboliczne charaktery-
Tabela 1. Skala oceny podstawowych czynności w życiu codziennym (ADL) - skala Katza

Table 1. Scale evaluation of basic activities of daily living (ADL) - Katz's scale

\begin{tabular}{lcc}
\hline Czynność & \multicolumn{2}{c}{$\begin{array}{c}\text { Samodzielność } \\
\text { chorego }\end{array}$} \\
\cline { 2 - 3 } & Tak & Nie \\
\hline Kąpanie się & 1 & 0 \\
Ubieranie się i rozbieranie się & 1 & 0 \\
Korzystanie z toalety & 1 & 0 \\
Wstawanie z tóżka & 1 & 0 \\
i przemieszczanie się na fotel & 1 & 0 \\
Samodzielne jedzenie & 1 & 0 \\
Kontrolowane wydalanie moczu & & \\
i stolca & & \\
\hline PUNKTACJA: & & \\
- 5-6 pkt. - sprawni & \\
• 3-4 pkt. - umiarkowanie niesprawni & \\
\hline$\leq 2$ pkt.— znacznie niesprawni &
\end{tabular}

styczne dla podeszłego wieku, które wywierają niezależny niekorzystny wpływ na wyniki leczenia nowotworów u osób starszych. Takim nowo poznanym niekorzystnym czynnikiem prognostycznym jest niedobór witaminy D. Bittenbring i wsp. [9] badali wpływ obniżonego stężenia witaminy D $\mathrm{u}$ starszych chorych na chłoniaka rozlanego $\mathrm{z}$ dużych komórek B (DLBCL, diffuse large B-cell lymphoma) na wyniki leczenia według protokołu CHOP$14 \pm$ rytuksymab prowadzonego $\mathrm{w}$ ramach badania RICOVER-60. Wykazano, że niedobór witaminy D określany na podstawie stężenia 25-OH-witaminy D3 wiązał się z krótszym przeżyciem wolnym od

Tabela 2. Skala oceny złożonych czynności życia codziennego (iADL) - skala Lawtona

Table 2. The instrumental activity of daily living (iADL) - Lawton's scale

\begin{tabular}{lccc}
\hline Pytanie & \multicolumn{3}{c}{ Odpowiedź } \\
\cline { 2 - 4 } & $\begin{array}{c}\text { Bez } \\
\text { pomocy }\end{array}$ & $\begin{array}{c}\text { Z niewielka } \\
\text { pomocą }\end{array}$ & $\begin{array}{c}\text { Nie jestem } \\
\text { w stanie }\end{array}$ \\
\hline 1. Czy potrafisz korzystać z telefonu? & 3 & 2 & 1 \\
2. Czy jesteś w stanie dotrzeć do miejsc poza odległością spaceru? & 3 & 2 & 1 \\
3. Czy wychodzisz na zakupy po artykuły spożywcze? & 3 & 2 & 1 \\
4. Czy możesz samodzielnie przygotować sobie posiłki? & 3 & 2 & 1 \\
5. Czy możesz samodzielnie wykonywać prace domowe (np. sprzątanie)? & 3 & 2 & 1 \\
6. Czy możesz samodzielnie majsterkować/wyprać swoje rzeczy? & 3 & 2 & 1 \\
7. Czy samodzielnie przygotowujesz i przyjmujesz leki? & 3 & 2 & 1 \\
8. Czy samodzielnie gospodarujesz pieniędzmi? & 3 & 2 & 1 \\
\hline
\end{tabular}

Maksymalnie 24 pkt. Ogólna liczba punktów ma znaczenie tylko w odniesieniu do konkretnego chorego; jej spadek w czasie świadczy o pogarszaniu się stanu ogólnego 
Tabela 3. Indeks chorób towarzyszących/współistniejących według Charlson (CCI) [16]

Table 3. Charlson's Comorbidity Index (CCI) [16]

\begin{tabular}{|c|c|}
\hline Jednostka chorobowa & $\mathrm{CCl}$ \\
\hline Zawał serca & 1 \\
\hline Zastoinowa niewydolność serca & 1 \\
\hline Choroba naczyń obwodowych & 1 \\
\hline Choroba naczyń mózgowych & 1 \\
\hline Otępienie & 1 \\
\hline Przewlekła choroba płuc & 1 \\
\hline Choroba tkanki łącznej & 1 \\
\hline Choroba wrzodowa & 1 \\
\hline Choroba wątroby o łagodnym nasileniu & 1 \\
\hline Cukrzyca bez powikłań narządowych & 1 \\
\hline Niedowład połowiczy & 2 \\
\hline $\begin{array}{l}\text { Choroby nerek o umiarkowanym lub ciężkim } \\
\text { nasileniu }\end{array}$ & 2 \\
\hline Cukrzyca z powikłaniami narządowymi & 2 \\
\hline Inne choroby nowotworowe bez przerzutów & 2 \\
\hline Białaczka & 2 \\
\hline Chłoniak & 2 \\
\hline $\begin{array}{l}\text { Choroba wątroby o umiarkowanym lub ciężkim } \\
\text { nasileniu }\end{array}$ & 2 \\
\hline Inne choroby nowotworowe z przerzutami & 3 \\
\hline AIDS & 6 \\
\hline
\end{tabular}

AIDS (acquired immune deficiency syndrome) - zespół nabytego niedoboru odporności

zdarzeń niepożądanych (EFS, event-free survival) i OS. Trzyletnie OS u chorych $z$ niedoborem witaminy D wyniosło $70 \%$, natomiast u chorych $z$ jej prawidłowym stężeniem $-82 \%$, a EFS, odpowiednio, $59 \%$ i $79 \%$. Stężenie $25-\mathrm{OH}$-witaminy D3 pozostało niezależnym od Międzynarodowego Wskaźnika Prognostycznego (IPI, International Prognostic Index) czynnikiem rokowniczym w analizie wielowariantowej OS $(\mathrm{p}=0,04)$ oraz EFS $(\mathrm{p}=0,008) . \mathrm{W}$ ostatnich latach są gromadzone coraz liczniejsze dowody na rolę witaminy D w odpowiedzi immunologicznej, regulacji cyklu komórkowego i apoptozy. Mechanizmy wpływu witaminy $\mathrm{D}$ na te procesy nie są do końca poznane. Bittenbring i wsp. [9] wykazali w cytowanym badaniu, że niedobór witaminy $\mathrm{D}$ zmniejsza indukowaną przez rytuksymab toksyczność komórkową. Ponadto autorzy dowiedli, że substytucja witaminy D odwraca to niekorzystne zjawisko. Na podstawie uzyskanych wyników autorzy stawiają wniosek, że suplementacja witaminy D może poprawić skuteczność rytuksymabu stosowanego u starszych chorych na NHL.
Badacze francuscy wykazali natomiast, że $\mathrm{u}$ chorych $\mathrm{w}$ starszym wieku leczonych $\mathrm{z}$ powodu DLBCL objawy związane $z$ kacheksją, tj. zanik mięśni szkieletowych i zanik tkanki tłuszczowej wykazywane w obrazowaniu metodą tomografii komputerowej oraz hipoalbuminemia, istotnie wpływają na odległe wyniki leczenia [10]. Na podstawie tych niekorzystnych czynników badacze skonstruowali wskaźnik prognostyczny ( $0 v .1 v .2-$ -3 czynniki), który w analizie wieloczynnikowej zachował niezależne od wieku, wartości IPI i wskaźnika masy ciała (BMI, body mass index) znaczenie rokownicze. Objawy związane $z$ kacheksją w bardziej dokładny sposób niż wartość BMI pozwoliły prognozować odległe przeżycie starszych chorych na DLBCL. Stwierdzono ponadto, że parametry antropometryczne związane z masą mięśni szkieletowych poprawily się u $25 \%$ chorych po leczeniu zgodnie ze schematem CHOP. Autorzy wnioskują zatem, że kacheksja w przebiegu DLBCL u starszych chorych jest procesem odwracalnym i jej leczenie powinno stanowić cel terapeutyczny realizowany równolegle $z$ leczeniem przeciwnowotworowym.

\section{Podsumowanie}

Cyklicznie publikowane zalecenia europejskich i amerykańskich towarzystw naukowych, dotyczące stosowania G-CSF w zapobieganiu FN indukowanej chemioterapią, zaowocowały coraz powszechniejszym ich stosowaniem w codziennej praktyce. W wielu pracach opublikowanych w ostatnich latach potwierdzono ich skuteczność w profilaktyce $\mathrm{FN}$ i utrzymaniu zaplanowanej intensywności chemioterapii u chorych na nowotwory układu chłonnego. W ostatnich latach coraz więcej uwagi poświęca się również zapobieganiu późnym niehamatologicznym powikłaniom chemioterapii. Na podstawie wyników badań, dotyczących ryzyka i częstości występowania powikłań sercowo-naczyniowych chemioterapii, opublikowano europejskie wytyczne dotyczące zasad monitorowania zaburzeń czynności lewej komory i stosowania wczesnej wtórnej kardioprotekcji farmakologicznej u chorych leczonych antracyklinami w celu obniżenia ryzyka wystąpienia jawnej klinicznie niewydolności serca. Prowadzone są również badania nad możliwością ochrony czynności gonad u kobiet poddawanych chemioterapii dzięki zastosowaniu agonistów GnRH. W populacji chorych na nowotwory w starszym wieku zidentyfikowano możliwe do skorygowania zaburzenia metaboliczne charakterystyczne dla podeszłego wieku, takie jak niedobór witaminy D i kacheksja, które niekorzystnie wpływają na 
Tabela 4. Cumulative IIIness Rating Scale for Geriatrics (CIRS-G) [16]

Table 4. Cumulative Illness Rating Scale for Geriatrics (CIRS-G) [16]

\begin{tabular}{|c|c|c|c|c|c|c|}
\hline \multirow{2}{*}{\multicolumn{3}{|c|}{$\begin{array}{l}\text { Choroby } \\
\text { 1. Choroby serca }\end{array}$}} & \multicolumn{4}{|c|}{ Punktacja } \\
\hline & & & 1 & 2 & 3 & 4 \\
\hline \multicolumn{3}{|c|}{$\begin{array}{l}\text { 2. Nadciśnienie tętnicze (oceniane na podstawie ciężkości; uszkodzenia narządowe oceniane } \\
\text { oddzielnie) }\end{array}$} & 1 & 2 & 3 & 4 \\
\hline \multicolumn{3}{|c|}{ 3. Choroby naczyń } & 1 & 2 & 3 & 4 \\
\hline \multicolumn{3}{|c|}{ 4. Choroby hematologiczne (układów krwiotwórczego i chłonnego) } & 1 & 2 & 3 & 4 \\
\hline \multicolumn{3}{|c|}{ 5. Choroby układu oddechowego (płuc, oskrzeli, tchawicy) } & 1 & 2 & 3 & 4 \\
\hline \multicolumn{3}{|c|}{ 6. Choroby oczu i otolaryngologiczne (uszu, nosa, gardła, krtani) } & 1 & 2 & 3 & 4 \\
\hline \multicolumn{3}{|c|}{$\begin{array}{l}\text { 7. Choroby górnego odcinka przewodu pokarmowego (przełyku, żołądka, dwunastnicy, } \\
\text { trzustki; nie obejmuje cukrzycy) }\end{array}$} & 1 & 2 & 3 & 4 \\
\hline \multicolumn{3}{|c|}{ 8. Choroby dolnego odcinka przewodu pokarmowego (jelit; przepukliny) } & 1 & 2 & 3 & 4 \\
\hline \multicolumn{3}{|c|}{ 9. Choroby wątroby i dróg żółciowych } & 1 & 2 & 3 & 4 \\
\hline \multicolumn{3}{|c|}{ 10. Choroby nerek } & 1 & 2 & 3 & 4 \\
\hline \multicolumn{3}{|c|}{$\begin{array}{l}\text { 11. Choroby układu moczowo-płciowego (moczowodu, pęcherza moczowego, cewki } \\
\text { moczowej, gruczołu krokowego, narządów płciowych) }\end{array}$} & 1 & 2 & 3 & 4 \\
\hline \multicolumn{3}{|c|}{ 12. Choroby skóry i układu szkieletowo-mięśniowego } & 1 & 2 & 3 & 4 \\
\hline \multicolumn{3}{|c|}{ 13. Choroby neurologiczne (mózgu, rdzenia kręgowego, nerwów obwodowych) } & 1 & 2 & 3 & 4 \\
\hline \multicolumn{3}{|c|}{$\begin{array}{l}\text { 14. Choroby endokrynologiczne i metaboliczne (cukrzyca, choroby tarczycy, otyłość, } \\
\text { zaburzenia elektrolitowe, zakażenia układowe, zatrucia) oraz choroby } \\
\text { gruczołu piersiowego }\end{array}$} & 1 & 2 & 3 & 4 \\
\hline \multicolumn{3}{|c|}{ 15. Choroby psychiczne (otępienie, depresja, niepokój, pobudzenie/majaczenie, psychoza) } & 1 & 2 & 3 & 4 \\
\hline Punkty & Dysfunkcja & \multicolumn{5}{|l|}{ Ocena chorób współistniejących } \\
\hline 0 & Brak & \multicolumn{5}{|l|}{ Funkcja narządu (układu) prawidłowa } \\
\hline 1 & Łagodna & \multicolumn{5}{|c|}{$\begin{array}{l}\text { Obecność choroby (upośledzenia funkcji) wymagającej lub niewymagającej leczenia, dobre } \\
\text { rokowanie, prawidłowa aktywność chorego (np.: zmiany skórne, przepukliny, żylaki odbytu) }\end{array}$} \\
\hline 2 & Umiarkowana & \multicolumn{5}{|c|}{$\begin{array}{l}\text { Obecność choroby (upośledzenia funkcji) wymagającej leczenia, dobre rokowanie, } \\
\text { ograniczona aktywność chorego (np.: kamica żółciowa, cukrzyca, złamania) }\end{array}$} \\
\hline 3 & Ciężka & \multicolumn{5}{|c|}{$\begin{array}{l}\text { Obecność choroby (upośledzenia funkcji) wymagającej natychmiastowego leczenia, } \\
\text { niepewne rokowanie, istotne ograniczenie aktywności chorego (np.: zastoinowa } \\
\text { niewydolność krążenia, rozedma płuc) }\end{array}$} \\
\hline 4 & Bardzo ciężka & \multicolumn{5}{|c|}{$\begin{array}{l}\text { Stan zagrożenia życia, złe rokowanie (np.: zawał serca, krwawienie z przewodu } \\
\text { pokarmowego, udar mózgu) }\end{array}$} \\
\hline
\end{tabular}

odległe wyniki leczenia. Można mieć nadzieję, że postępy w leczeniu wspomagającym, jakie się dokonały w ostatnich latach, bezpośrednio wpłyną na wydłużenie i poprawę jakości życia chorych poddawanych leczeniu przeciwnowotworowemu.

\section{Piśmiennictwo}

1. Aapro M.S., Bohlius J., Cameron D.A. i wsp. 2010 update of EORTC guidelines for the use of granulocyte-colony stimulating factor to reduce the incidence of chemotherapy-induced febrile neutropenia in adult patients with lymphoproliferative disorders and solid tumours. European Organization for Research and Treatment of Cancer. Eur. J. Cancer 2011; 47: 8-32.

2. http://www.nccn.org/professionals/physician_gls/pdf/myeloid_ growth.pdf
3. Chao C., Rodriguez R., Page J.H. i wsp. History of chronic comorbidity and risk of chemotherapy-induced febrile neutropenia in patients with non-Hodgkin lymphoma not receiving granulocyte colony-stimulating factor prophylaxis. Leuk. Lymphoma 2015; 56: 72-79.

4. Wang L., Baser O., Kutikova L. i wsp. The impact of primary prophylaxis with granulocyte colony-stimulating factors on febrile neutropenia during chemotherapy: a systematic review and metaanalysis of randomized controlled trials. Support. Care Cancer 2015 Mar 29 [złożone do druku].

5. Cooper K.L., Madan J., Whyte S. i wsp. Granulocyte colony-stimulating factors for febrile neutropenia prophylaxis following chemotherapy: systematic review and meta-analysis. BMC Cancer 2011; $23: 404$.

6. Giebel S., Thomas X., Hallbook H. i wsp. The prophylactic use of granulocyte-colony stimulating factor during remission induction is associated with increased leukaemia-free survival of adults with acute lymphoblastic leukaemia: a joint analysis of five randomised trials on behalf of the EWALL. Eur. J. Cancer 2012; 48: 360-367. 


\section{Hematologia 2015, tom 6, nr 1}

7. Hamaker M.E., Vos A.G., Smorenburg C.H. i wsp. The value of geriatric assessments in predicting treatment tolerance and all-cause mortality in older patients with cancer. Oncologist 2012; 17: 1439-1449.

8. Tucci A., Martelli M., Rigacci L. i wsp. Comprehensive geriatric assessment is an essential tool to support treatment decisions in elderly patients with diffuse large B-cell lymphoma: a prospective multicenter evaluation in 173 patients by the Lymphoma Italian Foundation (FIL). Leuk. Lymphoma 2014 Oct 9: 1-6 [złożone do druku].

9. Bittenbring J.T., Neumann F., Altmann B. i wsp. Vitamin D deficiency impairs rituximab-mediated cellular cytotoxicity and outcome of patients with diffuse large B-cell lymphoma treated with but not without rituximab. J. Clin. Oncol. 2014; 32: 3242-3248.

10. Camus V., Lanic H., Kraut J. i wsp. Prognostic impact of fat tissue loss and cachexia assessed by computed tomography scan in elderly patients with diffuse large B-cell lymphoma treated with immunochemotherapy. Eur. J. Haematol. 2014; 93: 9-18.

11. Todaro M.C., Oreto L., Qamar R. i wsp. Cardioncology: state of the heart. Int. J. Cardiol. 2013; 168: 680-687.
12. Curigliano G., Cardinale D., Suter T. i wsp. Cardiovascular toxicity induced by chemotherapy, targeted agents and radiotherapy: ESMO Clinical Practice Guidelines. Ann. Oncol. 2012; 23 (supl. 7): vii155-vii66.

13. Kalam K., Otahal P., Marwick T.H. Prognostic implications of global LV dysfunction: a systematic review and meta-analysis of global longitudinal strain and ejection fraction. Heart 2014; 100: 1673-1680.

14. Behringer K., Thielen I., Mueller H. i wsp. Fertility and gonadal function in female survivors after treatment of early unfavorable Hodgkin lymphoma (HL) within the German Hodgkin Study Group HD14 trial. Ann. Oncol. 2012; 23: 1818-1825.

15. Behringer K., Mueller H., Goergen H. i wsp. Gonadal function and fertility in survivors after Hodgkin lymphoma treatment within the German Hodgkin Study Group HD13 to HD15 trials. J. Clin. Oncol. 2013; 31: 231-239.

16. Charlson M.E., Pompei P., Ales K.L., MacKenzie C.R. A new method of classifying prognostic comorbidity in longitudinal studies development and validation. J. Chron. Dis. 1987; 40: 373-383. 